\title{
The VWRCA Index: Measuring a Country's Comparative Advantage and Specialization in Services. The Case of Poland
}

\author{
Roman Wosiek ${ }^{1}$ and Anna Visvizi ${ }^{1,2, * \text { (D) }}$ \\ 1 Institute of International Studies (ISM), SGH Warsaw School of Economics, Aleja Niepodległości 162, \\ 02-554 Warsaw, Poland; rwosiek@sgh.waw.pl \\ 2 School of Business \& Economics, Deree College-The American College of Greece, 6 Gravias Street, \\ Aghia Paraskevi, 513042 Athens, Greece \\ * Correspondence: avisvizi@gmail.com
}

Citation: Wosiek, Roman, and Anna Visvizi. 2021. The VWRCA Index:

Measuring a Country's Comparative Advantage and Specialization in Services. The Case of Poland. Economies 9: 48. https://doi.org/ $10.3390 /$ economies 9020048

Academic Editor: Aleksander Panasiuk

Received: 19 February 2021

Accepted: 29 March 2021

Published: 2 April 2021

Publisher's Note: MDPI stays neutral with regard to jurisdictional claims in published maps and institutional affiliations.

Copyright: (c) 2021 by the authors. Licensee MDPI, Basel, Switzerland. This article is an open access article distributed under the terms and conditions of the Creative Commons Attribution (CC BY) license (https:// creativecommons.org/licenses/by/ $4.0 /)$.

\begin{abstract}
In the extant body of literature on the servitization of the economy, on the one hand, and determinants of growth and development, on the other, the classic question of revealed comparative advantage (RCA) plays a prominent role. Regardless of the popularity, relevance, and validity of the use of the RCA as a part of multivariate queries on the above topics, this paper argues that the RCA alone offers a rather static insight into a country's economic performance. Most importantly, the classic take on the RCA does not allow us to query a country's comparative advantage and degree of specialization in the services sector. By inserting itself in the broader discussion on ways of bypassing the limitations inherent in the classic RCA index, this paper proposes a novel take on the RCA index, i.e., the Visvizi-Wosiek RCA (VWRCA) index, and, subsequently, applies it to the study of the evolution of the services sector in Poland over the period 2010-2019. The added value of the VWRCA index is threefold. (i) By recognizing the increasing role of services in the global economy, it serves as a useful tool in queries aimed at examining the structure of a given economy, the degree of specialization in the production of certain services, and the real revealed comparative advantage a country has in the production of a certain group/category of services. (ii) By focusing solely on services, the VWRCA index allows us to examine the volume and velocity of trade in services independently from the volume of trade in goods. (iii) Due to the resulting methodological accuracy, it enables the inclusion of a temporal dimension in the analysis, which in turn gives cues as to specific developments and the actual performance of a given economy regarding the evolution of the services sector.
\end{abstract}

Keywords: RCA; CRCA; VWRCA; servitization; methods; Poland; global economy

\section{Introduction}

In the rich body of literature on the servitization of the economy, on the one hand, and determinants of growth and development, on the other, the classic question of the revealed comparative advantage (RCA) is frequently discussed. Regardless of the popularity, relevance, and validity of the use of the RCA as a part of multivariate queries on the performance of specific economies, this paper argues that the RCA alone offers a rather static insight into a country's economic performance. Considering the importance of viewing developments in the global economy through more dynamic, conceptual, and methodological lenses, this paper makes a case, on the one hand, for the incorporation of the temporal dimension into the RCA research and, on the other, for a clear delineation of services in research focused on a country's comparative advantage and specialization. By means of addressing these two limitations, a correction to the classic RCA is proposed. In this sense, this paper adds to the debate on the RCA, its limitations, and ways of bypassing and/or correcting them. Hence, throughout the paper, several direct references to the so-called corrected revealed comparative advantage (CRCA) are made. In what follows, the RCA-CRCA nexus is explored to account for change in the relative and absolute change 
in a country's comparative advantage. It is argued that classic approaches to the RCA do not allow us to examine a country's comparative advantage and degree of specialization in the services sector. To bypass these shortcomings in research focusing on the classic RCA index, in this paper, a slightly modified RCA index, i.e., the Visvizi-Wosiek RCA (VWRCA) index, is proposed. To test its usefulness, the VWRCA index is then applied to the study of the evolution of the services sector in Poland over the period 2010-2019. The added value of this paper consists of its contribution to the debate on methods and methodologies suitable for capturing change as well as the evolution of the global economy. The model thus proposed is then tested against the developments in Poland and the evolution of its relative and absolute comparative advantage. The argument in this paper is structured as follows. In the following section, the searchlight is directed at the specificities of the RCA and CRCA. In the next section, the proof of the model is presented. Subsequently, drawing on data covering the period 2010-2019, the case of Poland is examined. Discussion and conclusions follow.

\section{The Role of Services in the Global Economy}

Progressive liberalization of international trade, including the service sector (cf. Alkraiji 2020), results in the so-called servitization of the economy and the building of a service economy (Spring and Araujo 2017; Buera and Kaboski 2012; Green and Ng 2017; Lafuente et al. 2017; Rees et al. 2020; Saeedi and Visvizi 2021). Services, in other words, represent an increasingly salient part of international trade, and therefore also of local, national, and regional economic systems. The share of services in creating added value tends to increase with the level of national income in individual economies. In the poorest ones, services generate around $40 \%$ to $50 \%$ of the gross domestic product (GDP), while in those with an average national income, i.e., above USD25,000 per capita (current prices), their share hovers around $60 \%$. In highly developed economies, services account for up to $70 \%$ of GDP (World Bank 2016). According to data for 2018, the service sector globally generated an average of $67.5 \%$ of GDP (UNCTAD 2020a).

The growing role of services in the world economy may be evidenced by the steady increase in their share in world trade since 1980. In 1980, the value of service exports remained at the level of 16\%, while in 2005, it exceeded 20\%. According to data for 2015, expressed in current prices, services traded internationally accounted for $23 \%$ of trade turnover (UNCTAD 2016). That the share of services in the global economy is increasing is also evidenced by the most recent, i.e., 2019, data on world trade. Specifically, in 2019, world total trade equalled USD24,722,088 in current prices (in millions). At the same time, the world's trade in services amounted to USD6,144,034 in current prices (in millions). Hence, the share of the service sector in total global trade was 25\% (UNCTAD 2020b).

Clearly, the upward trends presented above are subject to periodic fluctuations. Shortterm declines in value are frequent. The period of the 2008-2009 economic and financial crisis was one example of such deviations (Gulati and Kumar 2016; Zouaghi et al. 2018; Loungani et al. 2017; Bi et al. 2019; Ariu 2016). The scope of the implications of the COVID19 pandemic on the volume of trade, and especially on the volume of trade in services, is yet to be assessed and evaluated (Shingal 2020; Minondo 2021). Already now, however, the data suggests that the global trade in services declined by $23.3 \%$ year-over-year for the third quarter of 2020. The decline was particularly sharp in travel services, i.e., $67.1 \%$, and in transport services, i.e., 24.5\% (UNCTAD 2020c).

\section{The RCA Index: Its Origins and Limitations}

Comparative advantage (CA) is a classic concept well established within the classical theories of international trade. Initially formulated by David Ricardo in 1817 (Ricardo 1817; cf. Watson 2017), in response to Adam Smith's argument of absolute advantage, CA highlights the positive correlation between specialization, international division of labor, and the global output. Specialization, in this context, denotes a situation where a given country, in the face of a lack of natural or acquired absolute advantage in the production of 
a given good, makes a deliberate decision to embark on the production of a good, which is comparatively better than the rest of the goods that country can produce. Through specialization, and therefore also as a result of moving up the learning curve, over time, that country may substantially improve its competitive advantage in the production of that specific good (Herciu 2013; Balogh and Jámbor 2017). Under certain conditions, this may lead to increases in competitiveness (Siggel 2006). Considering that other countries do the same, over time, the quest for the acquisition of comparative advantage leads to specialization in international trade overall (Abbas and Waheed 2017). This process is exacerbated by the laws of mutual supply and demand in the world market (Lectard and Rougier 2018). In this view, comparative advantage may also be viewed as a determinant of an economy's trade structure. Clearly, the classic approach to a nation's comparative advantage as introduced by Ricardo has several limitations. In the context of the argument advanced in this paper, the key issue that needs to be highlighted is that Ricardo's approach was originally applied to trade in merchandise/goods. These limitations notwithstanding, the CA theory and the related notions of specialization, increases in efficiency, and greater global output form the thrust of the logic underpinning the contemporary multilateral trading system.

As a result, not only the CA theory, but also the index identifying comparative advantage is widely recognized as an indicator of specialization in international trade (Balassa and Noland 1989; cf. de Grauwe 2010). Moreover, the index is used in research exploring the international competitive position of an economy, including, in particular, its position in international trade in the world market (Misala 2005; Kuźniar 2007; Wosiek 2016). It should be stressed that comparative advantage is relative, dynamic, and multidimensional. It is conditioned by technological, political, economic, cultural, and environmental factors, as well as production factors, such as capital, labor, the availability of raw materials, and knowledge, as well as by the scale of production in a given country.

The most commonly used index to identify an economy's comparative advantages by sectors of production, commodity groups, or categories of services is the Balassa index of revealed comparative advantage (RCA) (Balassa 1965). Balassa's key point, and so the logic behind the RCA index, was that it was impossible to assess a country's (degree) of specialization in the production/exports of a given good, based solely on the volume and direction of that country's foreign trade. In line with Balassa, that would only be possible if we knew that country's specific comparative advantages over its international trading partners. Accordingly, by knowing the RCA index, an index that measures and, indeed, reveals the real comparative advantages that a country possesses, we can understand a country's degree and kind of specialization in the production of specific goods and services. This includes assessing the competitiveness of the exports of goods and, nowadays, also services. This RCA index provides information on the revealed comparative advantage based on an assessment of the share a group of goods or services has in a given economy's exports and in the world exports to a selected market.

The following equation offers a mathematical depiction/formula of the RCA index:

$$
R C A_{i j}=\frac{X_{i j}}{X_{j}}: \frac{X_{i}}{X} \text { or } R C A_{i j}=\frac{X_{i j}}{\sum_{i=1}^{n} X_{i j}}: \frac{X_{i}}{\sum_{i=1}^{n} X_{i}}
$$

where:

$R C A_{i j}$-revealed comparative advantage index,

$X_{i j}$-denotes the value of an economy's export of the $i$-th group of products (services) to country $j$,

$X_{j}$-total value of the $i$-th economy's exports,

$X_{i}$-value of the world export of the $i$-th group of products (services),

$X$-total world export value.

Thus, the RCA index expresses the ratio of the export value of a country's examined commodity group in this country's total export value to the share of the value of the world 
exports of that group of goods or services in the total world export value. The widespread use of this index results from its relatively simple formula and interpretation: values of the RCA index lower than 1 indicate that an economy has no comparative advantages; values within the interval $(1,2)$ indicate a weak comparative advantage; and those in the interval $(2,4)$ show a moderate advantage, while values over 4 signify a strong comparative advantage (Hinloopen and Marrewijk 2001; Deb and Sengupta 2017).

The RCA index is also used for assessing the competitiveness of an economy's exports in relation to selected trading partners or within an economic region or group. Its mathematical formula has the following form:

$$
R C A_{i j}=\frac{X_{i j}}{X_{j}}: \frac{X_{i}^{R}}{X^{R}}
$$

where:

$R C A_{i j}$-revealed comparative advantage index,

$X_{i j}$-denotes the value of an economy's export of the $i$-th group of products (services) to country $j$,

$X_{j}$-total value of the $i$-th economy's exports,

$X_{i}^{R}$-value of the world export of the $i$-th group of products (services) in partner countries,

$X^{R}$ _total export value in partner countries.

Numerous empirical studies explore modifications of the above formulas, their alternatives, and reinterpretations. Differences arise already at the stage of indices being constructed. This may be exemplified by a modified RCA index that takes into account an economy's import value as well:

$$
R C A_{i}=\frac{E X P_{i j}^{K}}{I M P_{i j}^{K}}: \frac{E X P_{j}^{K}}{I M P_{j}^{K}}
$$

where:

$R C A_{i}$-revealed comparative advantage index,

$E X P_{i j}^{K}$ - the value of the $i$-th group of products' export from economy $K$ to group $j$,

$I M P_{i j}^{K}$ - the value of the $i$-th group of products' import from economy $K$ to group $j$,

$E X P_{j}^{K}$ —world exports of economy $K$ to group $j$,

$I M P_{j}^{K}$-world imports of economy $K$ from group $j$,

$i$-product,

$K$-economy under analysis,

$j$-partner countries.

Each of the RCA indices mentioned above features certain advantages and limitations.

This means that when querying and applying RCA indices for the purpose of an analysis, a careful and critical interpretation of the results are needed. Especially, caution is needed in interpreting changes in values used for drawing conclusions about present or gained/lost comparative advantages. Accordingly, an important limitation of the two RCA indices is that the formulas take into account only the volume of export of an economy's commodity in relation to the total world exports of that commodity. This approach fails to accommodate the fact that there are non-zero transport costs between two countries-trading partners. Accordingly, including the total world exports in the equation obscures the view. Consequently, the revealed advantage determined in this way may be purely abstract, i.e., it may offer solely a model view of certain, and thus incomplete, factors necessary to understand and explain comparative advantages. What follows is that to determine the real revealed comparative advantage of an economy in relation to the countries with which it trades, only its trading partners should be considered, and not the world trade (Cieślik 2000).

Another limitation discussed in the literature (Salamaga 2013) is the fact that the RCA index is unstandardized, i.e., empirical distributions of the index values are generally 
characterized by strong asymmetry and lack of stability (Laursen 1998). This significantly limits the comparability of its values in terms of time and space. The lack of such stability, which also determines only the static approach, results, among other things, from the presence of a trade imbalance, i.e., significant fluctuations of trade deficit. In such a case, when advantages are examined in a dynamic approach, it is possible that the value of the index may increase, while at the same time, the competitive position of the economy may decrease, as measured by means of the particular commodity group's share in the market under consideration. Another drawback is that the values of the RCA index are sensitive both to the number of commodity groups and the number of countries in the reference group.

Considering the RCA's limitations that are identified and explored at length in the literature, attempts were undertaken to bypass these limitations. To this end, on the one hand, substantial effort was invested in improving the formulas of the RCA index, and, on the other hand, through empirical research aimed at confirming the real comparative advantages. In addition, the conceptually inclined debate sought to construct adjusted indices that, by means of bypassing the said limitations of the RCA, would incorporate corrections. It is in this context that the corrected RCA, or corrected revealed comparative advantage (CRCA), was proposed. This view offers an important addition to the classic RCA. Importantly, only by applying in an analysis both the RCA and CRCA in a combined manner, can we arrive at a correct interpretation of the data sets available. The following section elaborates on this issue.

\section{Bypassing RCA's Limitations: Toward the Corrected Revealed Comparative Advantage (CRCA) Index}

An interesting proposal on how to normalize the value of the RCA index (Dalum et al. 1998) suggests the following:

$$
R C A S_{i}=\frac{R C A_{i}-1}{R C A_{i}+1}
$$

where:

$R C A S_{i}$-adjusted RCA index,

$R C A_{i}$-Balassa index.

In a similar vein, another proposal aimed at improving the properties of the RCA index (Salamaga 2013) suggests the following generic formula:

$$
R C A_{k}^{(a)}=\frac{R C A_{i}^{a}-1}{R C A_{i}^{a}+1}
$$

where:

$R C A_{k}^{(a)}$-adjusted RCA index,

$R C A_{i}$-Balassa index,

$A$-positive number.

The formula proposed by Salamaga (2013) makes it possible to obtain a normalized value of the index in the interval $\langle-1,1\rangle$. Notably, the positive values of the index indicate the presence of the revealed comparative advantage in exports, while negative values indicate the absence of such an advantage. The closer the value of the index is to 1, the stronger the economy's revealed comparative advantage. On the other hand, the closer the value of the adjusted index is to $(-1)$, the greater the lack of comparative advantage of the studied economy. It should be noted here that the adopted value of the parameter $a$ in the exponent of the power determines the rate of convergence of the $R C A_{k}^{(a)}$ index to the limit values of the interval $\langle-1,1\rangle$.

Apart from the proposals of adjusted RCA indexed, as discussed above (Dalum et al. 1998; Salamaga 2013), several other contributions that aim at improving the explanatory value of RCA exist. The thrust of this debate is formed by the question of how to bypass the problem, inherent in the RCA, of distortions in trade flows. By resolving this issue, 
the RCA could then be used in a more dynamic manner, i.e., to examine and compare the values of RCA over time. A concept fulfilling this condition was initially proposed by Neven (1995), and was then highlighted in the debate again by Brodzicki (2011):

$$
C R C A_{i}=\frac{E X P_{i}}{\sum_{i=1}^{n} E X P_{i}}-\frac{I M P_{i}}{\sum_{i=1}^{n} I M P_{i}}
$$

where:

$C R C A_{i}$-adjusted RCA index,

$E X P_{i}$-value of the export of products belonging to the $i$-th sector or $i$-th commodity group, $I M P_{i}$ - value of the import of products belonging to the $i$-th sector or $i$-th commodity group.

The adjusted CRCA index takes values greater than zero when an economy has a real comparative advantage; otherwise, the index takes values equal to or less than zero.

Another example of modification in the original version of the RCA index is provided in the proposal by Yu et al. (2009). The authors argue that their index not only enables empirical studies of a specific subject to be conducted in static terms, but also makes it possible to compare their results over time and space. The normalized revealed comparative advantage index, i.e., the NRCA index determines the degree of deviation of an economy's actual exports from its level of comparative-neutral advantage, in relative terms, in relation to the world export market. It is believed that this approach provides a methodologically appropriate indication of the actual revealed comparative advantages (Hassan and Ahmad 2018; Proudman and Redding 2000). The mathematical formula of the NRCA index is given by the equation:

$$
N R C A_{k}^{i}=\frac{\Delta x_{i k}}{X}=\frac{X_{i k}}{X}-\frac{X_{k} X_{i}}{X X}
$$

where:

$N R C A_{k}^{i}$-adjusted RCA index in economy $i$ for commodity $k$,

$X_{i k}$ - export of commodity $k$ from economy $i$ to a selected trading partner, e.g., China,

$X_{i}$ - total value of the exports of economy to China,

$X_{k}$ - export of commodity $k$ to China by a given group,

$X$-export of a group to a specific market.

Studies have confirmed that the value of the NRCA index greater than zero indicates a higher level of the actual exports of commodities than do simulations of the revealed comparative advantages using the RCA. This is in line with the fundamental assumption in classical theories of international trade, according to which no country has advantage in the production of all commodities (Choroś-Mrozowska 2020; Krugman et al. 2015).

In brief, the short review of the three proposals (Dalum et al. 1998; Yu et al. 2009; Salamaga 2013) aimed at bypassing specific limitations inherent in the RCA index suggests that, the value of the classic RCA index notwithstanding, economists have always sought to devise more accurate formulas to measure diverse aspects of a country's comparative advantage. The literature confirms that the RCA, even in modified/enhanced variants, i.e., including the CRCA, remains popular as an important index to employ in empirical research. This paper entrenches itself in this strand of the debate. The following section substantiates this claim.

\section{The VWRCA Index: An Enhanced RCA Index}

Based on the discussion outlined in detail in previous sections, in this section, yet another way of bypassing the limitations inherent in RCA is proposed, i.e., the VWRCA index (Formula (8)). The VWRCA index derives from the following assumptions:

(a) servitization of the global economy gains in momentum;

(b) services are characterized by distinct, as compared to goods, qualities, such as immateriality, inseparability, and heterogeneity (Regan 1963; Godgson et al. 2014; Wosiek 2018); which 
(c) has implications for the volume and velocity of international trade in services; therefore

(d) it is imperative that an index is devised that captures developments and trends specific to specialization in the service sector alone, i.e., as a separate category in trade, not conflated with trade in general; and

(e) overall, it is argued that focusing on the service sector, separate from trade in goods, makes it possible to identify real revealed comparative advantages that a given economy has with regard to trade in services.

Against the backdrop of the five assumptions outlined above, the VWRCA index:

(i) employs the classic RCA index, as outlined in Formula (3), to selected services produced in a given economy;

(ii) takes into account both exports and imports of these services by that economy; however

(iii) instead of accounting for the overall volume of exports and imports of that economy, it incorporates solely the volume of international trade in services; and

(iv) in this vein, the VWRCA index may be defined as follows:

$$
V W R C A=\frac{E X P_{i}^{P}}{I M P_{i}^{P}}: \frac{\sum_{i=1}^{n} E X P_{i}^{P}}{\sum_{i=1}^{n} I M P_{i}^{P}}
$$

where:

$V W R C A-$ RCA index in the service sector,

$E X P_{i}^{P}$ - exports of an $i$ group/category of services of a given economy, e.g., economy $P$,

$I M P_{i}^{P}$-imports of an $i$ group/category of services of a given economy, e.g., economy $P$, where:

$i$-a group/category of services,

$n$-services sector in general.

The added value of the VWRCA index is threefold. (i) That is, while drawing from the classic RCA index, it adjusts the RCA to the realities of today's economy. In other words, it recognizes the increasing role of services in the global economy or, conversely, at the level of national economies. Therefore, it serves as a useful tool in queries aimed at examining the structure of a given economy, the degree of specialization in the production of certain services, and the real revealed comparative advantage a country has in the production of a certain group/category of services. In addition, (ii) by focusing solely on services, the $V W R C A$ index allows us to examine the volume and velocity of trade in services independently from the volume of trade in goods. Presumably, (iii) this methodological accuracy allows us to apply the $V W R C A$ index to examine specific time-defined data sets pertaining to trade in services. As a result, it enables quite a dynamic approach to the study of a country's real revealed comparative advantage in certain groups/categories of services. In other words, it gives cues as to the specific developments and actual performance of a given economy regarding the evolution of the services sector. That being said, we applied the VWRCA index to the examination of the service sector in Poland (cf. Malik 2018; Hashimoto and Wójcik 2020) over the period 2010-2019.

\section{Applying the VWRCA Index to the Study of Polish Service Sector (2010-2019)}

\subsection{VWRCA and the Case of Poland}

The objective of this section is to examine the significance of services in Polish exports and imports, and to indicate changes-both from static and dynamic perspectives-which took place over the period 2010-2019. Based on the analysis, Poland's comparative advantages in trade in services with its chief trading partners will be identified and examined over time from an ex post perspective. The research tool in this regard is the measure 
of specialization, i.e., the enhanced index of revealed comparative advantages-VWRCA (Equation (8)).

For comparative analysis over time, though, the VWRCA index will be adjusted to account for fluctuations in trade balance, and so a CRCA index will be determined (Equation (6)). By examining the values of both indices, VWRCA and CRCA, it will be possible to demonstrate Poland's real comparative advantages in trade in services over time.

\subsection{A Note on Methods and Materials}

Because of the complexity, dynamics, and relatively wide scope of research tasks to be conducted for the purpose of this analysis, methods that are characteristic of the field of economics will be used, i.e., non-reactive and logical methods: description, analysis, synthesis, systematization, verification, and deductive and inductive reasoning.

This study of changes in international trade in services is based on the statistics and classification proposed by United Nations Conference on Trade and Development UNCTAD, in which a dichotomous division of services is proposed. In brief, two groups of services are identified, i.e., services and other business services, i.e., related to manufacturing, transport, construction, insurance, pensions, etc.

Tables 1 and 2 contain the calculated values of Poland's revealed comparative advantage indices VWRCA and CRCA in world trade in services in 2010-2019.

Table 1. The Visvizi-Wosiek revealed comparative advantage (VWRCA) index of Poland's revealed comparative advantages in trade in services in 2010-2019.

\begin{tabular}{|c|c|c|c|c|c|c|c|c|c|c|}
\hline Service-Category & 2010 & 2011 & 2012 & 2013 & 2014 & 2015 & 2016 & 2017 & 2018 & 2019 \\
\hline Goods-related services, manufacturing services & 8.99 & 8.55 & 10.52 & 5.91 & 5.27 & 5.11 & 5.68 & 5.96 & 5.76 & 5.70 \\
\hline Maintenance and repair services & 3.31 & 3.84 & 2.48 & 1.31 & 1.08 & 1.48 & 1.60 & 1.83 & 1.72 & 1.75 \\
\hline Transport & 1.42 & 1.59 & 1.56 & 1.71 & 1.69 & 1.73 & 1.79 & 1.80 & 1.89 & 1.96 \\
\hline Travel, business & 0.65 & 0.89 & 0.97 & 0.87 & 1.17 & 1.42 & 1.57 & 1.90 & 2.07 & 2.27 \\
\hline Construction & 1.86 & 2.29 & 1.96 & 2.04 & 2.16 & 1.46 & 3.40 & 4.16 & 4.42 & 3.11 \\
\hline Insurance and pension services & 0.41 & 0.57 & 0.39 & 0.47 & 0.30 & 0.57 & 0.57 & 0.68 & 0.56 & 0.55 \\
\hline Financial services & 0.41 & 0.39 & 0.44 & 0.62 & 0.67 & 0.69 & 0.70 & 0.97 & 0.95 & 1.09 \\
\hline Charges for the use of intellectual property & 0.10 & 0.11 & 0.10 & 0.12 & 0.12 & 0.17 & 0.17 & 0.18 & 0.17 & 0.18 \\
\hline Telecommunications, computer, and information services & 0.91 & 1.08 & 1.16 & 1.20 & 1.41 & 1.59 & 1.70 & 1.75 & 1.83 & 2.07 \\
\hline Other business services & 1.31 & 1.21 & 1.25 & 1.18 & 1.22 & 1.24 & 1.27 & 1.36 & 1.42 & 1.53 \\
\hline Research and development (R\&D) & 3.62 & 3.81 & 3.56 & 2.91 & 3.45 & 3.81 & 3.40 & 4.71 & 5.31 & 6.40 \\
\hline Professional and management consulting services & 1.43 & 1.27 & 1.29 & 1.10 & 1.10 & 1.12 & 1.19 & 1.27 & 1.36 & 1.49 \\
\hline Personal, cultural, and recreational services & 0.33 & 0.33 & 0.34 & 0.50 & 0.53 & 0.63 & 0.89 & 0.92 & 1.38 & 1.54 \\
\hline Government services & 0.13 & 0.07 & 0.01 & 0.01 & 0.02 & 0.01 & 0.01 & 0.00 & 0.99 & 0.04 \\
\hline Commercial services & 1.15 & 1.22 & 1.24 & 1.30 & 1.33 & 1.37 & 1.46 & 1.53 & 1.58 & 1.65 \\
\hline Technical, trade-related, and other business services & 1.17 & 1.06 & 1.12 & 1.16 & 1.19 & 1.19 & 1.19 & 1.24 & 1.25 & 1.29 \\
\hline
\end{tabular}

Source: The authors, based on UNCTAD, Handbook of Statistics 2020.

Table 2. The corrected revealed comparative advantage (CRCA) adjusting index of Poland's comparative advantages in trade in services in 2010-2019.

\begin{tabular}{|c|c|c|c|c|c|c|c|c|c|c|}
\hline Service-Category & 2010 & 2011 & 2012 & 2013 & 2014 & 2015 & 2016 & 2017 & 2018 & 2019 \\
\hline Goods-related services, manufacturing services & 0.10 & 0.11 & 0.12 & 0.13 & 0.14 & 0.13 & 0.13 & 0.13 & 0.12 & 0.11 \\
\hline Maintenance and repair services & -0.06 & -0.05 & -0.06 & -0.15 & -0.18 & -0.14 & -0.13 & -0.11 & -0.13 & -0.13 \\
\hline Transport & 0.05 & 0.06 & 0.06 & 0.07 & 0.06 & 0.06 & 0.05 & 0.04 & 0.05 & 0.05 \\
\hline Travel, business & -0.04 & -0.02 & -0.01 & -0.02 & -0.01 & 0.00 & 0.00 & 0.01 & 0.01 & 0.01 \\
\hline Construction & 0.01 & 0.02 & 0.01 & 0.01 & 0.01 & 0.00 & 0.02 & 0.02 & 0.02 & 0.01 \\
\hline Insurance and pension services & -0.01 & -0.01 & -0.01 & -0.01 & -0.02 & -0.01 & -0.01 & -0.01 & -0.01 & -0.01 \\
\hline Financial services & -0.03 & -0.04 & -0.03 & -0.02 & -0.02 & -0.01 & -0.01 & -0.01 & -0.01 & -0.01 \\
\hline
\end{tabular}


Table 2. Cont.

\begin{tabular}{|c|c|c|c|c|c|c|c|c|c|c|}
\hline Service-Category & 2010 & 2011 & 2012 & 2013 & 2014 & 2015 & 2016 & 2017 & 2018 & 2019 \\
\hline Charges for the use of intellectual property & -0.07 & -0.06 & -0.06 & -0.07 & -0.07 & -0.06 & -0.07 & -0.07 & -0.07 & -0.08 \\
\hline Telecommunications, computer, and information services & -0.01 & -0.01 & 0.00 & -0.01 & 0.01 & 0.01 & 0.02 & 0.01 & 0.02 & 0.03 \\
\hline Other business services & 0.03 & 0.00 & 0.00 & -0.02 & -0.02 & -0.02 & -0.03 & -0.03 & -0.03 & -0.02 \\
\hline Research and development (R\&D) & 0.01 & 0.01 & 0.01 & 0.01 & 0.01 & 0.01 & 0.01 & 0.02 & 0.02 & 0.02 \\
\hline Professional and management consulting services & 0.02 & 0.00 & 0.01 & -0.02 & -0.02 & -0.03 & -0.03 & -0.02 & -0.02 & -0.01 \\
\hline Personal, cultural, and recreational services & -0.02 & -0.03 & -0.02 & -0.01 & -0.01 & -0.01 & -0.01 & -0.01 & 0.00 & 0.00 \\
\hline Government services & 0.00 & 0.00 & 0.00 & 0.00 & 0.00 & 0.00 & 0.00 & 0.00 & 0.00 & 0.00 \\
\hline Commercial services & 0.00 & 0.00 & 0.00 & 0.00 & 0.00 & 0.00 & 0.00 & 0.00 & 0.00 & 0.00 \\
\hline Technical, trade-related, and other business services & 0.00 & -0.02 & -0.01 & -0.01 & -0.01 & -0.01 & -0.02 & -0.2 & -0.02 & -0.02 \\
\hline
\end{tabular}

Source: The authors, based on UNCTAD, Handbook of Statistics 2020.

\section{Discussion}

The analysis of the VWRCA and CRCA indices specific to Poland over the period 2010-2019 suggests that the structure of Poland's revealed comparative advantages in trade in services substantially changed over that period of time.

First, the service capacity in the category of goods-related services, manufacturing services deteriorated dramatically. That is, the value of the VWRCA index gradually decreased from 8.99 in 2010 to 5.70 in 2019. This suggests that, assuming that the downward trend continues, the Polish economy may lose its comparative advantages in this area in a relatively short period of time. The situation is comparable for the category of maintenance and repair services, i.e., a decrease in the VWRCA value from 3.31 in 2010 to 1.75 in 2019 was observed. However, the values of the CRCA, i.e., less than zero, fail to confirm a comparative advantage in this category in the period under investigation.

Second, the area of transport services is characterized by a slight upward trend in terms of the real revealed comparative advantage.

Third, Poland not only held, but also strengthened its comparative advantages in services related to private and business travel. Advantages gained in these categories/groups of services over the period 2015-2019 are confirmed by positive and substantial values of the CRCA index essentially only since 2017. Notably, Tables 1 and 2 depict that the value of the CRCA in 2015 and 2016 was zero. It ought to be mentioned, though, that in the process of calculating the CRCA for respective years, a positive value would eventually appear; however only in tenth place after the comma.

Fourth, specialization in construction services, and relative advantages in this respect, gained in importance, i.e., the values of the VWRCA index increased from 1.86 to 3.11 in the examined period. A relatively small upward trend of the VWRCA index characterized the following service categories: insurance and pension services, and charges for the use of intellectual property. However, negative CRCA values in each of these categories indicate that these only theoretically determined advantages are not necessarily confirmed in reality, i.e., they may only result from a trade imbalance.

Fifth, two categories of services deserve attention: (1) telecommunications, computer, and information services; and (2) research and development (R\&D). For the first, the values of the VWRCA and CRCA indices suggest that in 2014, Poland gained an advantage over its trade partners. Moreover, this advantage is constantly strengthening. As for the second category of services, i.e., $\mathrm{R} \& \mathrm{D}$, a record percentage increase in the VWRCA value (77\%) was recorded over the period 2010-2019. This suggests that R\&D services in the chain of comparative advantages are in first place, with the highest share, among all the considered categories. It also shows the direction of a country's progressive specialization in services production and trade, and thus the process of building the service economy.

Sixth, the development of services in the area of personal, cultural, and recreational services looks optimistic. In other words, although Poland has no advantages in this sector, confronting the CRCA scores from 2010 to 2019 suggests that Poland might record 
further increases in comparative advantage in this category of services in the years to come. Notably, even if the value of the CRCA index was negative for the period 2010-2017, it was equal to zero for the period 2018-2019.

Seventh, throughout the period under examination, the VWRCA values greater than one (1) were also recorded in the categories of commercial services, and technical, traderelated, and other business services. Confronting these values with CRCA values makes it evident, however, that no real revealed comparative advantages exist. That is, the CRCA is zero for commercial services, and for technical, trade-related, and other business services it remained negative throughout the period considered.

\section{Conclusions}

This study deals with trade in services in a broad sense, yet the results of the analyses allow several conclusions to be formed. Poland is not a leader in international trade in services. It should be emphasized, however, that throughout the period under consideration, Poland's export and import markets developed intensively in the area of the specified groups of services. The market developed most intensively in the following groups/categories of services: travel, business, construction, financial services, telecommunications, computer and information services, and research and development (R\&D).

After 2010, a deterioration in capacity can be noted, and a real threat of losing the advantage in the category of goods-related services, manufacturing services. Nearly all the other categories show progress, except for government services, where no relative advantages were recorded. The Polish economy also has comparative advantages in relation to foreign countries in the categories of transport, construction, and research and development, and has a real chance to gain a comparative advantage in personal, cultural, and recreational services in the next several years. The threat of losing the advantage is noticeable in the category of goods-related services, manufacturing services.

The examination of the case of Poland, and specifically the analysis of the evolution of Poland's comparative advantage and specialization in services, offers several valuable insights into the patterns and trajectory of growth of the Polish economy. The development of the VWRCA index and its application in the analysis jointly with the CRCA index showcases the most straightforward, or orthodox, way of employing these indices in the analysis. What could be done in future research, though, would be to apply these indices in comparative research. Here, one of the possible avenues of research would focus on transition economies to explore ex post, for instance, the patterns and trajectories of respective economies' growth and development over a certain period of time. If, in addition, these factors were s correlated with the path and milestones of structural reforms and institutionalization of external relations in those counties, this kind of research would certainly add to the otherwise underestimated and underexplored field of the political economy of transformation (Csaba 2005; Visvizi and Tokarski 2014; Visvizi and Żukrowska 2020).

From a different angle, the progressing diversification of services and the emergence of specific groups/categories of services that are heavily dependent on advances in information and communication technology (ICT) prompt questions regarding the VWRCA's capacity to account for developments in services sector that thus arise. For instance, will it be justifiable to apply the same index to different groups/categories of services irrespective of their complexity and added value? Serious questions emerge as well regarding the capacity of the existing indices, including the VWRCA, to measure comparative advantage and specialization in services when services defy the existence of physical borders and jurisdictions. Consider the case of the ICT-enhanced platform economy, and correspondingly, gig economy, and the services necessitated by this.

Author Contributions: Conceptualization, R.W. and A.V.; Formal analysis, R.W. and A.V.; Funding acquisition, R.W. and A.V.; Methodology, R.W. and A.V.; Writing-original draft, R.W. and A.V.; Writing-review \& editing, R.W. and A.V. All authors have read and agreed to the published version of the manuscript. 
Funding: The authors would like to thank the SGH Warsaw School of Economics for supporting research reported in this paper through the grant "SGH Research potential 2021".

Institutional Review Board Statement: Does not apply.

Informed Consent Statement: Does not apply.

Data Availability Statement: Does not apply.

Conflicts of Interest: The authors declare no conflict of interest.

\section{References}

Abbas, Shujaat, and Abdul Waheed. 2017. Trade competitiveness of Pakistan: Evidence from the revealed comparative advantage approach. Competitiveness Review 27: 462-75. [CrossRef]

Alkraiji, Abdullah Ibrahim. 2020. An examination of citizen satisfaction with mandatory e-government services: Comparison of two information systems success models. Transforming Government: People, Process and Policy. [CrossRef]

Ariu, Andrea. 2016. Crisis-proof services: Why trade in services did not suffer during the 2008-2009 collapse. Journal of International Economics 98: 138-49. [CrossRef]

Balassa, Bela. 1965. Trade Liberalisation and 'Revealed' Comparative Advantage. Manchester School of Economics and Social Studies 33: 99-123. [CrossRef]

Balassa, Bela, and Marcus Noland. 1989. Revealed Comparative Advantage in Japan and the United States. Journal of International Economic Integration 4: 8-22. [CrossRef]

Balogh, Jeremiás Máté, and Attila Jámbor. 2017. The global competitiveness of European wine producers. British Food Journal 119: 2076-88. [CrossRef]

Bi, Yujiang, Robert J. Alexander, and Zhen Pei. 2019. Factors affecting trade in services: Evidence from panel data. Applied Economics 51: 3730-39. [CrossRef]

Brodzicki, Tomasz. 2011. Structural adjustments in trade relations of the Visegrad group countries. Paper presented at Thirteen Annual Conference, ETSG 2011, Copenhagen, Denmark, September 8-9; Available online: https:/ /www.etsg.org/ETSG2011/ETSG201 1Programme.html (accessed on 2 April 2021).

Buera, Francisco J., and Joseph P. Kaboski. 2012. The Rise of the Service Economy. American Economic Review 102: 2540-69. [CrossRef]

Choroś-Mrozowska, Dominika. 2020. Changes and Comparisons in Pattern of Polish Chinese Trade within the "16+1" Format. European Research Studies Journal XXIII: 4-5.

Cieślik, Andrzej. 2000. Nowa teoria Handlu Zagranicznego w Świetle Badań Empirycznych. Warszawa: Wydawnictwo Naukowe PWN, pp. 86-89.

Csaba, László. 2005. The New Political Economy of Emerging Europe. Budapest: Akadémiai Kiadó.

Dalum, Bent, Keld Laursen, and Gert Villumsen. 1998. Structural Change in OECD Export Specialisation Patterns: De-Specialisation and 'Stickiness'. International Review of Applied Economics 12: 423-43. [CrossRef]

de Grauwe, Paul, ed. 2010. Dimensions of Competitiveness. CESifo Seminar Series. Massachusetts: MIT Press, ISBN 9780262013963.

Deb, Kaveri, and Bodhisattva Sengupta. 2017. On Empirical Distribution of RCA Indices. IIM Kozhikode Society \& Management Review 6: 23-41. [CrossRef]

Godgson, Mark, David M. Gann, and Nelson Philips. 2014. The Oxford Handbook of Innovation Management. Oxford: Oxford Uniwersity Press.

Green, Maxwell. Philip Davies, and Irene Ng. 2017. Two strands of servitization: A thematic analysis of traditional and customer co-created servitization and future research directions. International Journal of Production Economics 192: 40-53. [CrossRef]

Gulati, Rachita, and Sunil Kumar. 2016. Assessing the impact of the global financial crisis on the profit efficiency of Indian banks. Economic Modelling 58: 167-81. [CrossRef]

Hashimoto, Tom, and Dariusz Wójcik. 2020. The geography of financial and business services in Poland: Stable concentration and a growing division of labour. European Urban and Regional Studies. [CrossRef]

Hassan, Mahboob, and Hafiz Khalil Ahmad. 2018. An Estimation of Normalized Revealed Comparative Advantage and its Determinants in Pakistan. Pakistan Vision 19: 231-57.

Herciu, Mihaela. 2013. Measuring International Competitiveness of Romania by Using Porter's Diamond and Revealed Comparative Advantage. Procedia Economics and Finance 6: 273-79. [CrossRef]

Hinloopen, Jeroen, and Charles van Marrewijk. 2001. On the Empirical Distribution of the Balassa Index. Weltwirtschaftliches Archiv 137: 1-35. [CrossRef]

Krugman, Paul. R., Maurice Obstfeld, and Mark J. Melitz. 2015. International Economics. Theory and Policy. Tenth Edition GLOBAL Edition. London: Pearson Education Limited, pp. 56-80.

Kuźniar, Andżelika. 2007. Usługi w Handlu Międzynarodowym [Services in International Trade]. Torun: Wydawnictwo Adam Marszałek.

Lafuente, Esteban, Yancy Vaillant, and Ferran Vendrell-Herrero. 2017. Territorial servitization: Exploring the virtuous circle connecting knowledge-intensive services and new manufacturing businesses. International Journal of Production Economics 192: 19-28. [CrossRef] 
Laursen, Keld. 1998. Revealed Comparative Advantage and the Alternatives as Measures of International Specialisation. DRUID Working Papers 98-30, DRUID. Aalborg: Copenhagen Business School, Department of Industrial Economics and Strategy/Aalborg University, Department of Business Studies.

Lectard, Pauline, and Eric Rougier. 2018. Can Developing Countries Gain from Defying Comparative Advantage? Distance to Comparative Advantage, Export Diversification and Sophistication, and the Dynamics of Specialization. World Development 102: 90-110. [CrossRef]

Loungani, Prakash, Saurabh Mishra, Chris Papageorgiou, and Ke Wang. 2017. World Trade in Services: Evidence from a New Dataset (March 2017). IMF Working Paper No. 17/77. Available online: https:/ / ssrn.com/abstract=2967432 (accessed on 2 February 2021).

Malik, Radosław. 2018. Key location factors and the evolution of motives for business service offshoring to Poland. Journal of Economics $\mathcal{E}$ Management 31: 119-32. [CrossRef]

Minondo, Asier. 2021. Impact of COVID-19 on the trade of goods and services in Spain. Applied Economic Analysis. [CrossRef]

Misala, Józef. 2005. Wymiana Międzynarodowa i Gospodarka Światowa. Teoria i Mechanizmy Funkcjonowania [International Exchange and the Global Economy]. Warszawa: Szkoła Główna Handlowa w Warszawie, p. 300.

Neven, Damien. 1995. Trade liberalisation with Eastern nations: Some distribution issues. European Economic Review 39: 622-32. [CrossRef]

Proudman, James, and Stephen Redding. 2000. Evolving Patterns of International Trade. Review of International Economics 8: 373-96. [CrossRef]

Rees, Daniel J., Victoria Bates, Roderick A. Thomas, Simon B. Brooks, Hamish Laing, Gareth H. Davies, Michael Williams, Leighton Phillips, and Yogesh K. Dwivedi. 2020. Collaborating to deliver value in health care: Exploring conditions required for successful healthcare and life science sector collaboration. Transforming Government: People, Process and Policy. [CrossRef]

Regan, William J. 1963. The Service Revolution. Journal of Marketing 27: 57-62. [CrossRef]

Ricardo, Ricardo. 1817. On the Principles of Political Economy and Taxation. London: John Murray, Albemarle-Street.

Saeedi, Kawther, and Anna Visvizi. 2021. Software Development Methodologies, HEIs, and the Digital Economy. Education Sciences 11: 73. [CrossRef]

Salamaga, Marcin. 2013. Badanie konkurencyjności polskiego eksportu z wykorzystaniem skorygowanego wskaźnika przewagi komparatywnej [Examining Polish exports competitiveness by means of CRCA]. Zeszyty Naukowe Uniwersytetu Ekonomicznego w Krakowie 904: 37.

Shingal, Anirudh. 2020. Services trade and COVID-19, Policy Paper 25 April 2020, VOX EU/CEPR. Available online: https:/ /voxeu. org/article/services-trade-and-covid-19 (accessed on 15 February 2021).

Siggel, Eckhard. 2006. International Competitiveness and Comparative Advantage: A Survey and a Proposal for Measurement. Journal of Industry, Competition and Trade 6: 137-59. [CrossRef]

Spring, Martin, and Luis Araujo. 2017. Product biographies in servitization and the circular economy. Industrial Marketing Management 60: 126-37. [CrossRef]

UNCTAD. 2016. Handbook of Statistics 2016-Economic Trends, Goods and Services (BPM6): Exports and Imports of Goods and Services, Annual. Geneva: UNCTAD.

UNCTAD. 2020a. Handbook of Statistics 2020—Economic Trends, Gross Domestic Product. Geneva: UNCTAD, pp. 4-5.

UNCTAD. 2020b. Handbook of Statistics 2020-Economic Trends, Goods and Services (BPM6): Exports and Imports of Goods and Services, Annual. Geneva: UNCTAD.

UNCTAD. 2020c. Handbook of Statistics 2020-Economic Trends, International Trade in Services Q3 2020. Geneva: UNCTAD, p. 1.

Visvizi, Anna, and Paweł Tokarski. 2014. Poland and the Euro: Between lock-in and unfinished transition. Society and Economy 36: 445-68. Available online: http://www.akademiai.com/content/n06q579u42h248xh/ (accessed on 15 February 2021). [CrossRef]

Visvizi, Anna, and Katarzyna Żukrowska. 2020. Transition and transformation: The case of Poland. In Poland in the Single Market: Politics, Economics, the Euro. Edited by Anna Visvizi, Anna Matysek-Jedrych and Katarzyna Mroczek-Dąbrowska. London: Routledge, pp. 13-32.

Watson, Matthew. 2017. Historicising Ricardo's comparative advantage theory, challenging the normative foundations of liberal International Political Economy. New Political Economy 22: 257-72. [CrossRef]

World Bank. 2016. World Development Indicators 2016. Washington: World Bank, pp. 108-9.

Wosiek, Roman. 2016. Handel Międzynarodowy Towarami Wysokiej Techniki i Zaawansowanej Technologii-Przykład Polskiego Rynku w Latach 2004-2013 [International Trade in Technologically Advanced Goods: The Case of Poland (2004-2013)]. Warszawie: Rozwój we Współczesnym Świecie, Uwarunkowania, Wyzwania, Perspektywy, Oficyna Wydawnicza SGH Szkoła Główna Handlowa w Warszawie, pp. 543-55.

Wosiek, Roman. 2018. Service Innovation: A New Paradigm in the Current Technological Revolution. Katowice: Studia Ekonomiczne, Zeszyty Naukowe Uniwerystetu Ekonomicznego w Katowicach, vol. 352, pp. 278-86.

Yu, Run, Junning Cai, and Ping Sun Leung. 2009. The normalized revealed comparative advantage index. Annals of Regional Sciences 43: 267-82. [CrossRef]

Zouaghi, Ferdaous, Mercedes Sánchez, and Marian García Martínez. 2018. Did the global financial crisis impact firms' innovation performance? The role of internal and external knowledge capabilities in high and low tech industries. Technological Forecasting and Social Change 132: 92-104. [CrossRef] 